\title{
Валерій ПАПЧЕНКО
}

\section{ІНТЕРАКТИВНІСТЬ ШУМІВ І ПАУЗ У ЗВУКОВОМУ ОБРАЗІ ФІЛЬМУ}

Стаття присвячена взаємодії тиші і шумів у кіно. Будучи включеними у єдину систему звукового образу фільму, тиша і шуми перебувають у стані інтеракції, щьо виражена в естетичній, семантичній і психологічній сферах. На основі аналізу конкретних фільмів показано багатоаспектність функиіонування і взаємного впливу тиші і шумів.

Ключові слова: кінематограф, звуковий образ фільму, тиша, шуми, пауза, звукорежисура, саунд-дизайн.

Статья посвящена взаимодействию тишины и шумов в кино. Будучи включенными в единую систему звукового образа фильма, тишина и шумы находятся в состоянии интеракиии, выраженной в эстетической, семантической и психологической сферах. На основе анализа конкретных фильмов показана многоаспектность функиионирования и взаимного влияния тишины и шумов.

Ключевые слова: кинематограф, звуковой образ фильма, тишина, шумы, пауза, звукорежиссура, саунд-дизайн.

The article is devoted to the interaction of silence and noises in the cinema. Being incorporated into a single system of sound image of the film, silence and noises are in a state of interactivity expressed in the aesthetic, semantic and psychological spheres. Based on the analysis of specific films, multifunctioning and mutual influence of silence and noises are shown.

Key words: motion film, sound image of the film, silence, noises, pause, sound engineering, sound design.

Питання взаємодії візуальної і звукової сфер кінематографа здавна цікавило теоретиків. Так, одним 3 перших на цю тему висловлювався ще С. Ейзенштейн. 3 часу появи звукового кіно питання аналізу ролі звуку у сприйнятті фільму досліджені досить широко. Вочевидь, першим об'єктом для наукової рефлексії стала саме музика у фільмі. Цим проблемам присвячені фундаментальні праці 3. Лісси, T. Корганова й I. Фролова, серед сучасників - Т. Шак («Музика у структурі медіатексту»). Поряд з двома, безперечно, важливими компонентами кінозвуку мовою і музикою - інтерес дослідників викликають шуми і пауза. Водночас аналіз звукового образу фільму у сукупності всіх його елементів $€$ нечастим явищем у наукових розвідках. Так, в українському мистецтвознавстві чи не єдиною суттєвою працею у даному напрямі є дисертація О. Бут [2]. Серед авторів, що так чи інакше торкались цієї сфери, також можна назвати Л. Трахтенберга, В. Маньковского, Р. Казаряна, Ю. Закревського, але це переважно вузькоспеціалізовані праці.
Проблематика функціонування шумів і паузи у кіно, як загалом і сфера саунд-дизайну, є доволі малодослідженим явищем. Саме цим і обумовлена актуальність статті.

Аналіз наукових розробок дав змогу зробити висновок: дослідники доволі фрагментарно звертаються до шумів і паузи, досліджуючи їхній можливий взаємозв'язок і взаємовплив. Саме тому метою нашої статті $є$ виявлення інтерактивності (взаємозв'язку, взаємовпливу, взаємної трансформації) таких важливих компонентів звукового фільму, як шуми і паузи, і у даному контексті - аналіз їхньої ролі у формуванні емоційної звукової палітри фільму.

Як зазначає Р. Ширман, «Шуми - один з найцікавіших виразних засобів. Їх вміле використання може надати всьому фільму або певному його епізоду абсолютно нової якості» [7, 107]. Відносно паузи автор цікаво зазначає: «Тиша, пауза це не руйнування або знищення звукового ряду, а найважливіші елементи звукової виразності» 
[7, 121]. У праці відомого кінознавця В. Горпенка також відзначається важлива роль паузи: «Тиша, мовчання - це не відсутність звуку. Це особливий стан, який набуває певного значення». Також автор робить цікаве спостереження: «Пауза в фільмі завжди містить в собі відлуння попереднього» $[3,203]$. 3. Лісса влучно стверджує, що «шум тоді має право на існування і перетворюється у художній засіб, коли він сам що-небудь додає до кадру, а не тільки супроводжує кадр» $[5,240]$. У дисертації М. Срмишевої проведено глибоке дослідження ролі шумів у телевізійному документальному фільмі і наголошується їх важливість і специфічність у цьому жанрі, але не досліджено роль паузи [4].

У професійній лексиці для позначення «відсутності» використовуються два терміни: «пауза» $\mathrm{i}$ «тиша». Варто внести певну ясність у їхню семантику, оскільки термін «тиша» видається у контексті даної статті більш перспективним. 3розуміло, що ці два терміни у певній своїй частині $є$ синонімічними, разом з тим, маємо й принципову відмінність. «Пауза» апелює до утилітарного аспекту, «тиша» - до онтологічного. Пауза часто $\epsilon$ вимушеною (або принаймні запланованою) зупинкою певного процесу. Наприклад, пауза у нотах музичного твору. Відтак у терміні «пауза» завжди наявний певний дисциплінарний присмак - як те, що повинно бути дотриманим. При цьому пауза нічого не повідомляє нам про власний стан речей - лише про те, що процес перервався. При цьому пауза $\epsilon$, по суті, бінарною ознакою («так/ ні»), позбавленою усякої двозначності та релятивності. Паузу неможливо уявити «більшою» або «меншою» за глибиною, лише за тривалістю. Тож пауза позбавлена якісних характеристик, будучи цілком нейтральним позначенням міри часу. Як «секунда», «хвилина» чи «місяць».

Тиша, напроти, має глибинний вимір, що автоматично ставить питання про відносність звукової матерії. Тиша ніколи не буває абсолютною, тому є, передусім, функцієєю драматургії. До того ж, тиша апелює радше не до стану конкретного процесу, а до стану простору загалом. Фактично тиша надає часу додаткового виміру - виміру глибини. Якщо пауза має відношення до «об'єктивного» часу (такого, який можна виміряти), то тиша ймовірніше апелює до суб'єктивного переживання часу. Пауза просто триває, тоді як тиша наповнена. Відтак тиша не сповіщає про відсутність, вона завжди має на меті певну ємність, що прагне бути заповненою. Саме через цей аспект тиша несе чимале смислове навантаження.
Парадоксально, але тишу можна відчути і не релятивно. Пригадаємо хоча б вислів «звучання тиші». Пауза завжди містить у собі певний діяльнісний аспект. Зробити паузу можна лише у тому процесі, який $\epsilon$ власноруч «запущеним» і контролюється. Тоді як тиша є положенням речей, які раптово прийшли до певного стану. Звісно, можна сказати, що тиша настає в результаті дії паузи. Але це, по-перше, не факт, а по-друге, для настання тиші потрібен збіг обставин, більший, аніж просто воля того, хто «ставить на паузу». Тиша є сукупністю об'єктивних і суб' єктивних факторів, не лише «акустики». Тож ми доходимо простого висновку: пауза є «інструкцією», що виникла за сценою перформативних мистецтв; технічним терміном, котрий відміряє час. Тиша є категорією. Причому категорією як мистецтва, так і самого життя.

У кожному з напрямів звукорежисури (кіно, студія, театр, концерт, телебачення, радіо) є місце для художнього самовираження митця. Майстерність звукорежисера, хоч у якій би з зазначених сфер він працював, завжди базується на: а) здатності творчо використовувати звук як засіб створення художніх образів («звук, як виражальний засіб»); б) точно виконувати операції запису i мікшування; в) умінні знайти ефективний спосіб запису. Залишивши за дужками дві останні сторони мистецтва звукорежисера (безперечно, дуже важливі), розглянемо особливості використання шумів і паузи (тиші) в кіно, зокрема, їхній взаємозв'язок і взаємовплив у контексті формування емоційної картини кінофільму. Шуми і тиша відіграють важливу роль у сприйнятті ідей режисера, i тут важко не погодитися 3 великим Джорджем Лукасом, який вважав звук одним 3 найважливіших компонентів фільму [8].

Взаємодія тиші і шумів у кіно апелює до давнього фундаментального питання музики як того мистецтва, що виникає «поміж паузами». Але якщо в музиці пауза є життєдайною силою ритму i без пауз не обходиться жодна (практично) п'єса, то у кінематографі повна звукова пауза $є$ швидше винятком, аніж правилом. Але при цьому саме пауза відкриває фундаментальну можливість, закладену у всіх перформативних мистецтвах якийсь час бути відсутнім. Зображення у кіно не може бути цілком відсутнім із зрозумілих причин. Врешті-решт візуальність - «головний канал» цього виду мистецтва. Звук витісняється на рівень підсвідомості (принаймні те, що не стосується його семантичної функціï) $[2,54]$. Але саме звук лишається тією єдиною силою, за допомогою якої кіно здатне найбільш гостро усвідомити свою ча- 
соплинність, оскільки лише звук у просторі фільму може дозволити собі розкіш якийсь час взагалі не існувати. Саме слух є «аналізатором часу», як стверджують психологи, тому не дивно, що звук у кіно $є$ носієм тонких аспектів темпоральності, у тому числі на часових проміжках, що перевищують розподільчу здатність зору людини.

Звуковий образ сучасного фільму є складною багатокомпонентною системою, що поєднує у собі різні типи організації простору, різні семантичні «нашарування», різні хронотопи; окрім того, безліч різних типів технік і технологій, за якими стоїть праця десятків співробітників звукового цеху. Вочевидь, будучи системою (а не просто механістичним поєднанням), між елементами звукового образу $є$ певна інтеракція, що виявляється у різних формах: дифузія, конвергенція i дивергенція, взаємна деформація та мутація. Тож саме системність структури звукового образу фільму являє собою цікавий матеріал для аналізу мистецтвознавців.

Взаємодія тиші і шумів являє собою граничний випадок інтеракції звукових елементів, оскільки маємо справу відразу і з «буттям», i 3 «небуттям», які одночасно перетікають одне в одне. Тут ми торкаємось саме лімітів звуку як такого. Як відомо, верхньої межею семантичної організації звуку $є$ білий шум, коли складність структурних зв'язків i інтенсивність подій призводять до відчутного ефекту «хаосу». Нижньою межею, цілком логічно, є тиша. Але в природі не існує ані абсолютно білого шуму (оскільки це означатиме нескінченний спектр), ані абсолютної тиші. Будь-яка «тиша» $\mathrm{e}$ потенційним шумом, а будь-який шум - лише раптово вихопленим фрагментом тиші.

У цьому сенсі цікавим є дослідження взаємодії шумів і тиші з позиції психоакустики. Як відомо, динамічний діапазон людського слуху (близько 140 дБ) обмежений порогом чутності знизу і больовим порогом зверху. Але адаптаційні можливості слуху дають можливість легко зміщувати поріг чутності, як це успішно доводять експерименти у безеховій камері або при постійному навантаженні слуху гучними звуками (внаслідок чого чутливість зменшується). Наприклад, психологічний ефект від «зміщення порогів» давно став жанровим кліше у фільмах жахів, коли гучні шумові (або шумо-музичні) акценти несподівано роздирають тишу, сповнену зловісним передчуттям.

Якщо розглядати шуми і тишу як компоненти цілісного звукового «тіла» фільму, то стає зрозумілим, що шуми, будучи «складками» цього тіла, формуючи його рельєф, ніколи не бувають повні- стю відірваними від тиші, на тлі якої вони народжуються. Це сприяє уявленню їх як єдиного «континууму», або процесу перетікання звукової енергії, із власними точками згущення і розрідження. Будь-який шум просякнутий тишею, а тиша у будь-який момент може вибухнути шумом. Відповідно, до аналізу шумових фактур фільму може бути застосована також і інша методологія, окрім звичного аналізу їхньої семантики. Наприклад, спектроморфологія Деніса Смоллі [6], що бере початок із теорії П'єра Шеффера і застосовується для аналізу конкретної й електронної музики.

Скажімо, Смоллі веде мову про різні типи «впізнавання» - кореляції звуку і його джерела. Причому момент невпевненості щодо походження звуку (при відсутності візуального зв'язку) може стати потужним виражальним фактором саме у кіно. Так, доволі часто ми стикаємось не лише із закадровим використанням шумів, а й із шумами і звуковими ефектами, походження яких $є$ незрозумілим, щоб не сказати загадковим. Це типовий прийом для фільмів жахів, ефект саспенсу яких часто грунтується саме на ситуації семантичної невизначеності звукових і візуальних елементів.

Оскільки кіно, як будь-який вид мистецтва, $\epsilon$ засобом передачі дійсності через художню образність, доречно шукати причини трансформації шумового ландшафту фільму у реальному акустичному оточенні, що також еволюціонує разом iз науково-технічними прогресом. Зофья Лісса згадує, що на першому етапі існування звукового кіно музика ілюструвала практично кожен рух у кадрі $[5,118]$. Згодом ця своєрідна гіпернасиченість поступилася місцем більш розважливому використанню музичного ресурсу. Відсутність тиші у сучасному кіно легко пояснюється насиченим звуковим ландшафтом індустріального світу. 3 появою електричного виробництва з'явились нові типи шумів, наприклад, так званий «continuous noise», або «hum» $[9,125]$, що остаточно залишили людину без відчуття тиші. Відповідно до того, що «речей» у світі стало набагато більше, то й сучасний шумовий ландшафт став перенасиченим.

Про зникнення тиші з нашого життя свого часу виразно писав Жан Бодрійяр: «...надлишок знань байдуже розсіюється по поверхні в усіх напрямах, при цьому лише відбувається заміна одного слова іншим. Інтерфейс під'єднує співрозмовників одне до одного, як штекер у електричній розетці. Комунікація відбувається шляхом єдиного миттєвого циклу, і для того, щоб усе йшло добре, необхідний темп - часу для тиші не лишається. Тиша вигнана 3 екранів, вигнана 3 комуні- 
кації. Зображення, що їх надають засоби масової інформації (а тексти подібні до зображень), ніколи не змовкають: зображення повідомлень мають прямувати одне за одним безперервно» $[1,22]$.

Засновник акустичної екології Мюрай Шефер використовує для цього стану довкілля термін «lo-fi» $[9,76]$. Французький філософ Анрі Лефевр свого часу ввів термін «виробництво простору». Це певною мірою можна віднести і до простору акустичного. Із розвитком екології звуку і взагалі із підвищенням уваги до шумового забруднення, постало питання про контроль акустичного простору, про створення окремих зон зі зниженим шумовим навантаженням. 3 певного моменту «тиша» стала не просто акустичним феноменом, а й суспільною цінністю. Справді, виробництво акустичного простору відтепер фокусується навколо тиші, яка 3 природної «даності» перетворилась на продукт, котрий має цінність і на вироблення якого потрібно витрачати певні технічні та людські ресурси.

Певну аналогію можна провести і $з$ кіно. Із становленням гіпернасиченого «барокового» звукового образу $[2,110]$, особливо із розвитком систем просторового звучання тиша почала осмислюватись не просто як «пауза» у звучанні, а як специфічний виразний елемент, ефективність якого зростає пропорційно до загальної насиченості шумового ландшафту. Можна сказати, що у кіно сьогодні спостерігається навіть не виробництво тиші, а виробництво дефіцииту тиші. Тож ми вже не можемо розглядати тишу у кіно як «стихійне» явище, що просто відділяє одне від одного музичні фрази, діалоги і шуми. Радше тиша виникає як специфічний продукт картографії звукового ландшафту фільму, як цінний ресурс. Але, незважаючи на його цінність, надмірна наявність тиші у фільмі несе іншу загрозу. Розвиток технологій і становлення розгалуженого звукового цеху у кіновиробництві вимагає не лише дотримання певної якості звучання, а й забезпечення потрібної міри насиченості. Така тенденція загалом характерна для економіки споживання з ії гаслом «швидше, більше, сильніше». Зниження рівня інтенсивності спричинить гальмування економіки, тож сьогодні зовсім «тихі» фільми нікому не потрібні. Таким чином, тиша включена у подвійну економічну логіку: цінною одночасно $€$ і іiї наявність, i іiі відсутність.

Відомо, що звук у фільмі може виконувати декілька функцій, головними з яких є ілюстративна (безпосередня прив'язка звуку до зображення) i асоціативна (розширення рамки відеокадру за рахунок стимулювання, домислювання глядачем).
У перші роки звукового кінематографа режисери залюбки ілюстрували звуком будь-які внутрішньокадрові події. Спочатку це викликало захоплення глядачів, але 3 часом такий шаблонний прийом дедалі більше втрачав виразність. Згодом режисери зрозуміли, що набагато ефективніше спрацьовують більш складні звукові фактури, ніж суто ілюстративні. У кіно з'явилася «поліфонічність» шумового оформлення.

Як і всі компоненти фільму, звук схильний до художнього відбору і організації. При цьому звуковий ряд фільму піддається критичному аналізу як з боку його творців, так і з боку глядачів. Від того наскільки збігаються ці результати, залежить успіх фільму. Разом з відеорядом звук формує образну фактуру фільму, більш того, звук може мати самостійне смислове навантаження і створювати власні художні образи. Приклад цього - класичний фільм «Мертвий сезон» (реж. Сава Куліш), де оригінально використані шуми і тиша. Стеження за головним героєм-розвідником супроводжується стоп-кадрами з гучними клацаннями фотоапарата i подальшою паузою, причому вони взаємопов'язані: чим гучніше клацання затвора, тим більш зловісною здається пауза. В цьому разі можна стверджувати, що в цих сценах саме звук, а не зображення містить головне емоційне навантаження. Асоціативності доречно підіграють «холодні» звуки клавесина (відстороненість, тривога), клацання затвора (небезпека, постріл, арешт), тиша (смерть, небуття). Це той рідкісний випадок, коли звукорежисер фільму Галина Гаврилова певною мірою «переграла» кінооператора. Запропоноване нею звукове рішення сцен вичерпно передає драматизм ситуації в кадрі: вимкніть звук - і зникне трагедійна сутність епізодів і загострення пристрастей.

Відомо, що звук, безпосередньо прив'язаний до зображення (положення, руху) його джерело в кадрі виконує банальну ілюстративну функцію, але в сучасному кіно ілюстративність не є головним завданням. Наприклад, звук цокання годинника (що так полюбився кінорежисерам) частково оздоблює кадр з годинником, але нічого не додає до глибинного сенсу зображення. Коли ж годинника в кадрі немає, але звук його чутний, таке рішення різко розширює рамки сприйняття в бік його емоційного домислювання глядачем. Асоціації 3 цоканням годинника можуть означати багато: і невблаганний плин часу, і близьку трагічну розв'язку, тривогу очікування, тобто викликати у глядача ширші асоціації. Але де пауза у цій сцені?

У психоакустиці відомий «ефект годинника», коли мозок людини через деякий час після появи 
монотонного ударного звуку починає його ігнорувати, наприклад, звук барабана або маятника. Саме тому ми не чуємо будильник, що цокає всю ніч біля нашого вуха, хоча він постійно посилає імпульси в наші слухові рецептори. Тобто пауза 3 годинником в цьому кіно-прикладі стає віртуальною, нечутною.

Подібний підхід до асоціативного звуку може внести у фільм потужний емоційно-драматичний смисл. Застосування ж звуків лише за ознакою їхнього суто службового, ілюстративного призначення (наприклад, на екрані скаче кінь - чутно тупіт його копит) не обов'язково підведе глядача до задуманих авторами асоціацій. Для розуміння ідеї авторів звуковим фактурам, як і зображенню, слід надати відповідну форму: лише тоді вони будуть акцентувати сенс дії. Приклад: при відтворенні запису свисту кулі в фільмі «Матриця» режисерів братів Вачовські первинний записаний в тирі звук кулі при його відтворенні через гучномовці студії не лише не передавав стрімкість руху в кадрі, а й узагалі слабко «читався», різко знижуючи зорове сприйняття швидкості. Уповільнене відтворення фонограми і обробка іiї в комп'ютерних програмах вирішили проблему в бік асоціативності; звук став швидкісним, пронизливим і польотним. Тож не дивно, що цей фільм отримав чотири «Оскари», серед яких дві премії «за кращий звук» $\mathrm{i}$ «кращий монтаж звукових ефектів».

Вибір звукової фактури може відтінятися контекстом кадру. Приклад: той самий шумовий ефект (наприклад, гудок пароплава), залежно від оточення і зображення, може передати кілька характерів: сумний, тривожний, комічний тощо. За прикладами далеко ходити не варто - звернімось хоча б до класичних фільмів «Волга-Волга» Григорія Александрова (комічний, упевнений), «Жорстокий романс» Ельдара Рязанова і «Титанік» Джеймса Кемерона (тужливий, трагічний). I тут важлива пауза між гудками, котра додатково відтіняє їхню фактурну приналежність, взаємозв'язок, інтерактивність.

На наш погляд, найбільш образний і складний в роботі вид кінозвуку - це пауза. Пауза далеко не порожнеча, це елемент звуку, точніше його відсутність [7]. На жаль, драматична сила паузи (тиші) в кіно використовується досить нечасто. Пауза, яка виникла не випадково, а предметно і цілеспрямовано, може містити в собі значний смисловий акцент. Приклад: у фільмі з характерною назвою «Тиша» Володимира Басова героїня доторкається рукою до маятника годинника, зупиняючи його. Звук годинника змінює тиша: для героїні час зупинився. Інший приклад: війна, вибухи, солдати. У якийсь момент звук вибухів різко зникає, і настає мертва тиша. Глядач крупним планом бачить широко відкриті очі воїна... Ми розуміємо, що воїн втратив слух, він контужений, і глядач теж уже не чує вибухів (тут виявляється інтроспективний підхід, про який ітиметься нижче). Потужній вибух вплинув на появу подальшої мертвої кінематографічної тиші.

Абсолютна звукова пауза не завжди рівноцінна тиші. В кіно вважається, що якщо кінематографічна тиша триває більше 5-6 секунд, то вона має бути «розбавлена» будь-якими звуками другого плану - тихим шурхотом, потріскуванням дров у каміні, неголосним нявчанням кота тощо, інакше така пауза здається глядачеві нестерпно довгою (знову - взаємозалежність шумів і паузи). Приклад: герой, що причаївся в нічному лісі, навколо повна тиша. Цю картину через деякий проміжок часу звукорежисери поєднують 3 характерними для нічного лісу звуками - тихим хрускотом гілки під ногами, шурхотом листя, цвіркунами. Природно, ці шуми (при документальному підході до звуку в образному кіно) мають відповідати контексту: можна, звичайно, на тлі нічного лісу запустити гучний звук працюючого гідронасосу або уривки промов М. Горбачова - але це вже буде справжній авангард! До речі, таку авангардність в звукові, гротескно змішану з документальністю в культовому фільмі «Кін-дза-дза!», чудово використовує звукорежисер Катерина Попова-Еванс.

Вибір звуків, що акомпанують тиші, багато в чому залежить від сюжетної лінії фільму. Це може бути все що завгодно, що наголошує саме драматичну роль тиші в даний момент, головне доречність цих звуків. До оригінальних знахідок при «вклеюванні» відрізків тиші в звукову палітру фільму можуть привести лише творчі пошуки і фантазія звукорежисера, з подальшим зіставленням цих вклейок з конкретним відеорядом, його сенсом і настроєм дії. Справжня тиша - велика рідкість і коштовність XXI століття, і нею ніяк не можна нехтувати у сучасному кіно.

Художній звуковий образ виникає в творчому процесі, його підказує фантазія звукорежисера, суб'єктивне сприйняття якого значно впливає на вибір звукового рішення фільму. Для одного і того ж епізоду, наприклад, щоб висловити звуком стан тривоги, одному звукорежисерові знадобиться використати закадрові кроки героя, іншому - віддалений гуркіт грому, а третій обере мертву паузу.

Діалектику тиші і шумів також слід розглянути як функцію інтроспекиії. Погляд людського ока 
подібний до світлового променя, що «висвічує» фрагменти реальності. Завжди має місце точка зору. Візуальний ряд фільму завжди є точкою зору, цей «погляд» завжди є локальним (нехай і постійно змінюється), адже він має чіткі просторові координати («звідки ми дивимось») і оперує певною дистанцією, хоча цей погляд і відбувається зазвичай зі сторони «третьої персони». Щодо звукового ряду фільму ситуація доволі неоднозначна. По-перше, специфіка сприйняття звуку людиною апелює до інших просторових принципів, аніж зір. Тут варто використовувати метафору «сфери» замість зорового «променя». Відтак звуковий образ фільму не має визначеної локальності у кожен момент часу.

Якщо немотивована (закадрова) музика, якої в фільмі більшість, звучить «нізвідки», не маючи на власному тілі слідів зображуваного акустичного середовища, то закадрові шуми так чи інакше локалізовані. Принаймні вони мають власне джерело, реальне чи уявне. Але плановість шумового ряду художнього кіно є більш умовною, ніж плановість візуальна. Частково це пов'язано iз дотриманням необхідного рівня розбірливості шумів, адже наближення до «радіусу гулкості» неодмінно загрожуватиме якості звучання внаслідок ослаблення поля прямого звуку. Відтак принцип документальної достовірності поступився естетиці. Загалом естетика шумового оформлення сучасного кіно (а надто масового кіно) може бути охарактеризована як «аугментативна» - спрямована на перебільшення. Така тенденція бере початок ще 3 часів Джека Фолі.

Технології перезапису шумів у нейтральних студійних умовах дають змогу отримати максимально чіткий, рельєфний шумовий ряд, позбавлений негативного впливу натурального акустичного середовища, де відбуваються зйомки. Тому зрозуміло, що плановість шумів тяжіє до певного «укрупнення» порівняно із плановістю візуальною. Не буде значним перебільшенням сказати, що сучасне кіно намагається «нейтралізувати» первинне акустичне поле, а сам шумовий ряд при цьому глибоко синтетичний - змонтований із сотень «клаптиків», що мають різне походження і можуть взагалі не корелювати зі своїми екранними референтами, маючи цілком відмінне реальне джерело (яке саме - часто знають лише саунд-дизайнери).

Отже, шумовий ряд сучасного кіно існує у певному сенсі поза «точкою зору». Якщо будьякий ракурс камери чітко демонструє позицію спостерігача, то звучання шумів і діалогів часто $\epsilon$ ідеалізовано-нейтральним, як нібито вухо спостерігача було наближене на певну фіксовану відстань одночасно до практично усіх внутрішньокадрових джерел звуку, сприймаючи звуковий ландшафт максимально детально, що, звісно, $є$ недосяжним в реальних умовах слухацького досвіду. Шумовий ряд сучасного кіно є у певному сенсі мікроскопічним (чи, логічніше, мікрофонічним). Але слухова мікроскопія, на відміну від візуальної, не $\epsilon$ «звуженням променю» $\mathrm{i}$ «наведенням на фокус», вона $\epsilon$ саме функцією рельєфу, цілком адитивною, що передбачає граничне насичення і деталізацію без звуження «горизонту». Якщо зміна візуальної дистанції так чи інакше призводить до «фільтрації» певних елементів (оскільки око не може одночасно дивитись в усіх напрямах на 360 градусів і фокусуватись одночасно на усіх предметах), то для слуху, як більш «поліфонічного» органу, є цілком нормальною ситуація співіснування одночасно кількох планів із надмірним рівнем деталізації - словом, те, чого у природних умовах не може відбутись хоча б через неможливість забезпечити власним вухам «всеприсутність», яка саме і має місце при багатомікрофонному запису і при синтезуванні звукового образу фільму. Зауважимо, що терміни «субстрактивний» $\mathrm{i}$ «адитивний» (по відношенню до формування звукового образу) запозичені з дослідження О. Бут [2]. Щоправда, у цій статті терміни використано у більш вузькому, «технічному» сенсі.

Інтроспекція, про яку йдеться, є ефектом цілеспрямованого звуження звукового горизонту від «всеприсутності» до конкретної «точки зору». Інтроспективний шумовий рельєф $є$ вираженням сприйняття дійсності з точки зору конкретного персонажа. При цьому відбувається не «додавання», а «віднімання», своєрідна фільтрація крізь призму персоналізованого сприйняття. Часто до подібного прийому вдаються за наявності певних «додаткових» акустичних умов. Наприклад, у фільмі «Гравітація» (реж. Альфонсо Куарон) під час виходу героїв у відкритий космос ми чуємо певні шуми у спотвореному вигляді - так, якби ïх направді можна було б почути крізь скафандр (якби звук міг поширюватись у вакуумі, звісно). Інший широко вживаний прийом - імітація сприйняття звуку людьми із вадами слуху (як це відбувається, скажімо, у фільмі «It's All Gone Pete Tong», реж. Майк Доус) або відтворення певного фізичного чи психологічного стану героя (раптове запаморочення, шок, травма тощо). Так, у фільмі «Пил» (реж. Сергій Лобан) розпач головного героя під час прогулянки демонструється практично повною тишею, що різко контрастує зі змістом самих кадрів, наповнених людськими постатями, які рухаються і розмовляють. 
Діалектика шумів і тиші в інтроспективних епізодах виявляється передусім у зіставленні реального шумового рельєфу з віртуальним - опосередкованим сприйняттям героя. Тут можна навести приклад «зворотної фільтрації», коли зовнішня тиша переростає у «голоси» всередині героя або просто обертається нестерпним шумом його власної свідомості. Такий прийом, щоправда, засобами музики (нехай і доволі «шумоподібної»), часто використовується у фільмі «Сяйво» Стенлі Кубрика. В усякому разі, у подібних випадках виявляється релятивність шуму і тиші, їхня здатність переростати одне в одне крізь призму людського сприйняття. Зрештою, внутрішня «тиша» людини, що поміщена в безехову камеру, згодом обертається на шум течії іï власної крові у судинах.

Отож шуми і тиша $є$ фундаментальними компонентами звукового образу фільму i, будучи в системній єдності, перебувають у постійній взаємодії. Шуми і тиша не є дискретними елементами, вони формують єдиний звуковий континуум. У взаємодії даних елементів виявляється їхня релятивність. Інтеракція шумів і тиші виявляється не лише через драматургію фільму (тобто функціонально), а й психоакустично.

Звуковий образ сучасного художнього кіно демонструє здебільшого «агументативну» (спрямовану на перебільшення) естетику. Шумовий ряд $є$ гіпердетальним і сформований «адитивно» - додаванням безлічі фрагментів, що можуть мати абсолютно різне акустичне походження. Позиціонування шумів демонструє «зближення» плановості, що часто не збігається з плановістю зображення. Сприйняття шумів відбувається з позиції «усеприсутності», частково ігноруючи умови реального слухацького досвіду (такі, як акустична перспектива і локалізація). Це здійснюється для збагачення шумової палітри при збереженні максимальної чіткості, відтак виконуючи не лише естетичну, а й семантичну функцію. Разом із тим став можливим прийом «інтроспекції» - свідомого звуження перцептивного горизонту задля передачі «точки зору» конкретного персонажа. У статті також здійснено спробу семантичного аналізу понять «тиша» $\mathrm{i}$ «пауза» $\mathrm{i}$ обгрунтовано перспективність використання саме першого з них.

Майстерність звукорежисера завжди проявляється в художній мотивації, сміливості в застосуванні звукових фактур, образної виразності та точності зв'язку з контекстом фільму, бо вдале звукове тло - запорука успішного фільму. Саме у цьому контексті автор вбачає подальші мистецтвознавчі дослідження даної тематики.

\section{Джерела та література}

1. Бодрийяр Ж. Прозрачность зла / Жан Бодрийяр. - М. : Добросвет, 2000. - 258 с.

2. Бут О. В. Звук як компонент образної структури фільму : дис. ... канд. мистецтвознавства : 17.00.04 / Бут Оксана Василівна. - К., 2007. - 196 с.

3. Горпенко В. Архітектоніка фільму. Кадр. Монтаж. Фільм. Питання режисерської майстерності. Частина II. Монтаж / В. Г. Горпенко. - К. : Видавництво КДІТМ, 1997. $232 \mathrm{c}$.

4. Ермишева М. Звук как пластически-смысловое выражение идеи телевизионного документального фильма : автореф. дис. на соискание уч. степени канд. искусствоведения : спец. 17.00.13 «Кино-, теле- и другие экранные искусства» / М. Н. Ермишева. - М., 2010. - 21 с.

5. Лисса 3. Эстетика киномузыки / Зофья Лисса ; пер. с нем. А. О. Зелениной, Д. Л. Каравкиной. - М. : Музыка, 1970. $-494 \mathrm{c}$

6. Смирнов А. Спектроморфология. / Андрей Смирнов [Электронный ресурс]. - Режим доступа : http://asmir. info/lib/spectromorphology.htm

7. Ширман Р. Умное телевидение. Мастер-класс / Р. Н. Ширман. - К. : ЗАО Телерадиокурьер, 2011. - 360 с.

8. Dabbs, A. The revolution will not be televised: How Lucas modernised audio in film / Alistair Dabbs // The Register [Електронний ресурс]. - Режим доступу : https://www. theregister.co.uk/2017/05/26/star_wars_new_hope_40 lucas_revolutionises_cinema_sound/

9. Schafer, M. The Soundscape : Our Sonic Environment and the Tuning of the World / Murray R. Schafer. - Rochester, VT : Destiny Books, 1994. -320 p.

\section{References}

1. Bodryiiar, Zh. (2000). Prozrachnost zla. - Moscow : Dobrosvet, 258 [in Russian].

2. But, O. V. (2007). Sound as component of vivid structure of film: dys. ... kand. mystetstvoznavstva : 17.00.04. - Kyiv, 196 [in Ukrainian].

3. Horpenko, V. (1997). Arkhitektonika filmu. Kadr. Montazh. Film. Pytannia rezhyserskoi maisternosti. Chastyna II. Montazh. - Kyiv : Vydavnytstvo KDITM, 232 [in Ukrainian]..

4. Ermisheva, M. (2010). Zvuk kak plasticheski-smyislovoe vyirazhenie idei televizionnogo dokumentalnogo filma : avtoref. dis. na soiskanie uch. stepeni kand. iskusstvovedeniya : spets. 17.00.13 «Kino-, tele- i drugie ekrannyie iskusstva», 21 [in Russian].

5. Lissa, Z. (1970). Estetika kinomuzyiki ; per. s nem. A. O. Zeleninoy, D. L. Karavkinoy. - Moscow : Muzyika, 494 [in Russaian].

6. Smirnov, A. Spektromorfologiya. - URL : http://asmir.info/ lib/spectromorphology.htm

7. Shirman, R. (2011). Umnoe televidenie. Master-klass. Kyiv : ZAO Teleradiokurer, 360 [in Russian].

8. Dabbs, A. The revolution will not be televised: How Lucas modernised audio in film // The Register. - DOI : https://www. theregister.co.uk/2017/05/26/star_wars_new_hope_40_ lucas_revolutionises_cinema_sound/

9. Schafer, M. (1994). The Soundscape : Our Sonic Environment and the Tuning of the World. - Rochester, VT : Destiny Books, 320 [in England]. 